\title{
THE EFFECT OF CAPITAL STRUCTURE, LIQUIDITY AND PROFITABILITY ON COMPANY VALUE IN THE FOOD SUB SECTOR AND BEVERAGES ON THE INDONESIA STOCK EXCHANGE
}

\author{
By \\ Ni Wayan Rudini ${ }^{1}$, Gusti Ayu Mahanavami ${ }^{2}$, Nyoman Parta ${ }^{3}$, Ni Nyoman Menuh ${ }^{4}$ \\ 1,2,3,4 Program Studi Manajemen' STIMI Handayani, Denpasar \\ Email: ${ }^{1}$ andinwayan@gmail.com, ${ }^{2}$ gustiayumahanavami@gmail.com, ${ }^{3}$ parta.kmbp@gmail.com, \\ 4nyomanmenuh61@gmail.com
}

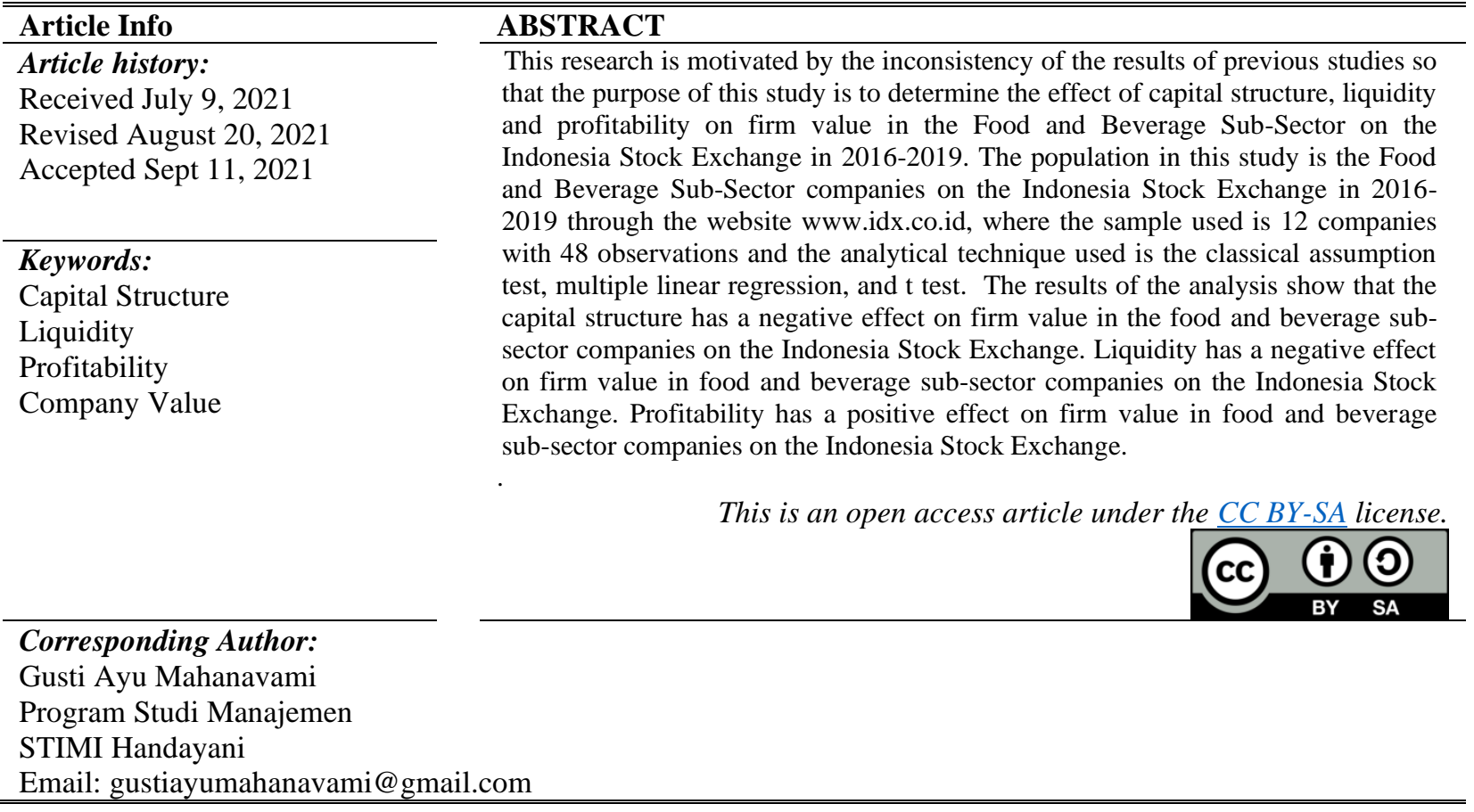

\section{INTRODUCTION}

Firm value is the selling price of the company that potential investors are willing to pay when the company is about to be sold [1] Wiagustini, 2014. There are many measuring tools that can be used to measure company value. One of them that is often used is price to book value (PBV) which is a comparison of stock price with book value per share. Price to book value (PBV) can show the extent of the efforts made by the company in creating company value relative to the amount of funds that have been invested. Price to book value (PBV) measures the value that the market places on management and change organizations as a growing company (Brigham and Houston, 2011:11). The increase in price to book value (PBV) indicates an increase in the prosperity of shareholders, which is the main goal of a go public company.

Based on the theory of capital structure, if the position of the capital structure is above the target of the optimal capital structure, then any increase in debt will reduce the value of the company. Therefore, it can be seen that the use of debt will increase the value of the company but only up to a certain point. After that point, the use of debt actually reduces the value of the company (Dewi, et al. 2014). The capital structure indicator used in this study is the debt to equity ratio (DER). Research on the effect of capital structure on firm value has been carried out by many researchers and there are still inconsistencies in the research results (research gap) so that the capital structure variable deserves to be studied. (Chaidir, 2015) states that the capital structure with the debt to equity ratio (DER) indicator has a significant positive effect on firm value with the price book value (PBV) indicator. Prasetia et al. (2014) stated that the capital structure does not have a significant positive effect on firm value. Dewi et al. (2014) 
stated that capital structure has a significant positive effect on firm value. Riaz (2016) and Winarto (2015) in their research also state that capital structure has a positive influence on firm value. In contrast to Mandalika (2016) states that capital structure does not have a significant relationship with firm value. Corry and Rustam (2013) state that the capital structure with the debt to equity ratio (DER) indicator has no significant effect on firm value.

The indicator that will be used in this research is return on equity (ROE). Return on equity (ROE) is a ratio that shows the company's ability to generate net income to return shareholder equity. ROE is a financial ratio used to measure the profitability of equity. The greater the ROE, the better the company's performance (Dewi, et al. 2014). There have been many studies on the effect of profitability on firm value, but there are still inconsistencies in the results so that there is a research gap and this is worthy of further research. Dewi and Ary (2013) stated that profitability has a positive effect on firm value. Hermuningsih (2013) states that profitability has a significant influence on firm value. Riaz (2016) and Winarto (2015) state that profitability has a positive effect on firm value. Likewise, according to Sudiani and Ayu (2016) stated that profitability has a significant positive effect on firm value. However, it is different from Corry and Rustam (2013) which states that profitability with return on equity (ROE) indicators does not have a significant effect on firm value. Chaidir (2015) also states that profitability with the return on assets (ROA) indicator has no effect on firm value with the price to book value (PBV) indicator. Jacob and Fadli (2017) state that liquidity has a negative effect on firm value.

The discrepancy in the results of previous studies motivates to conduct another study with the aim of knowing the Effect of Capital Structure, Liquidity and Profitability on Firm Value in the Food and Beverage SubSector on the Indonesia Stock Exchange.

\section{Theoretical Foundation}

\section{1) Signalling Theory}

According to Brigham and Houston (2011), signal theory explains management's perception of the company's future growth, which will affect the response of potential investors to the company. The signal is in the form of information that explains management's efforts in realizing the owner's wishes so that this information is an important indicator for investors and business people, especially in terms of making investment decisions. Information that has been submitted by the company and received by investors will be interpreted and analyzed first whether the information is a positive signal which will increase the value of the company or if investors give a negative signal indicating that the desire of investors is decreasing which will affect the decline in company value (Jogiyanto, 2010).

\section{2) Company Value}

The main purpose of establishing a company is to optimize the value of the company by maximizing the prosperity of its shareholders. Company value is the selling price of the company that potential investors are willing to pay when the company is sold. The higher the value of the company, the greater the prosperity that will be received by the owner of the company (Wiagustini, 2014:9). An indicator that can be used by investors in assessing the company as a whole is by looking at the high value of the company which can be reflected in its share price. Therefore, a high company value is important for investors.

\section{3) Capital Structure}

The capital structure is an illustration of the form of the company's financial proportions, namely between owned capital originating from long-term debt and own capital which is a source of financing for a company (Fahmi, 2016: 184). Capital structure is a combination of debt and equity in the company's long-term financial structure. Capital structure is an important issue for companies because the good or bad of the capital structure will have a direct effect on the company's financial position which in turn will affect the value of the company (Brigham F. \& Houston, 2010). According to Yuliana, et al (2013), capital structure theory is related to the effect of changes in capital structure itself on firm value assuming constant investment decisions and dividend policy. According to research by Brigham and Houston (2013), the optimal capital structure for a company is defined as a structure that will maximize the share price of a company. The capital structure is concluded as a company's funding mix that must be managed properly so as to maximize the value of a company.

\section{4) Liquidity}

Sartono (2014:114) states that liquidity is the company's ability to meet short-term financial obligations on time. High liquidity value reflects the company's high ability to meet its short-term obligations. Companies that have good liquidity values will be considered to have good performance by investors. High liquidity shows the strength of the company in terms of the ability to meet current liabilities from current assets owned so that this increases the confidence of outsiders in the company.

\section{5) Profitability}


International Journal of Social Science (IJSS)

Vol.1 Issue.3 October 2021, pp: 145-150

ISSN: 2798-3463 (Printed) | 2798-4079 (Online)

Profitability or profit is income minus expenses during the reporting period (Dewi and Wirajaya, 2013). The profitability ratio measures the overall management effectiveness which is indicated by the size of the level of profit obtained in relation to sales and investment (Fahmi, 2016: 80). If the company's ability to generate profits increases, the stock price will also increase, so that the company's value will also be higher (Husnan, 2012: 317).

Thinking Framework

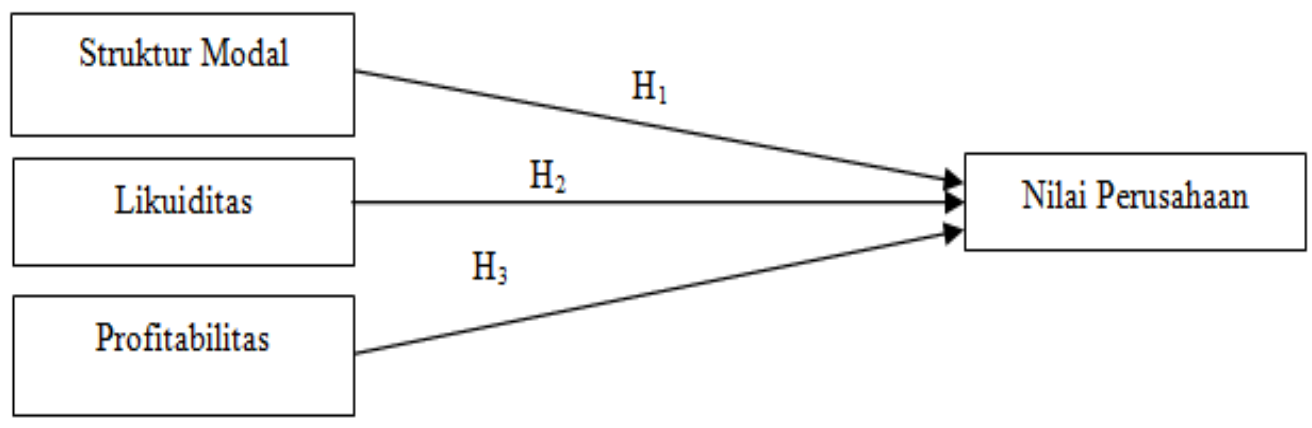

Gambar 1. Kerangka Berpikir

\section{Research Hypothesis}

Based on the background and theory and the results of previous research, the following hypotheses can be formulated:

H1: Capital structure has a negative effect on firm value

$\mathrm{H} 2$ : Liquidity has a positive effect on firm value

H3: Profitability has a positive effect on firm value

\section{RESEARCH METHOD}

This research was conducted in food and beverage sub-sector companies on the Indonesia Stock Exchange for the 2016-2019 period by accessing data on the official website of the Indonesia Stock Exchange at www.idx.co.id. The population of food and beverage sector companies on the Indonesia Stock Exchange from 20162019 amounted to 14 companies. Sampling was done by purposive sampling method so that the number of samples obtained was 12 companies. The data analysis technique used in this study is multiple linear regression analysis to determine the effect of capital structure, liquidity and profitability on firm value and the t-test shows the effect of individual independent variables on the dependent variable (Ghozali, 2016:99). The decision-making criteria are if the significance value is $>0.05$ then it does not have a partially significant effect on the independent variable on the dependent variable, and vice versa if the significance value is 0.05 then the independent variable has a partially significant effect on the dependent variable.

\section{RESULTS AND ANALYSIS (10 PT)}

\subsection{Classic assumption test}

\section{a. Normality test}

The results of the Kolmogorov-Smirnov test of the variables of capital structure, liquidity, profitability and company value in the food and beverage sub-sector on the Indonesia Stock Exchange show that the value of Asymp. Sig. (2tailed) of 0.070 is greater than 0.05 . This means that all data are normally distributed.

\section{b. Multicollinearity Test}

The results of multicollinearity testing of the effect of capital structure, liquidity, profitability and company value in the food and beverage sub-sector on the Indonesia Stock Exchange show that the tolerance value for the three independent variables is greater than 0.1 and the VIF value is less than 10. Thus, the regression model multiple linear regression is independent of multicollinearity, meaning that there is no correlation between the independent variables in the multiple linear regression model.

\section{c. Autocorrelation Test}

Based on the results of the calculation of the autocorrelation test using the Durbin-Watson test (DW-test) obtained a value of 2.359 so it can be concluded that there is no autocorrelation in this study, which is indicated by the value $1.50<2.359<2.50$. 


\section{d. Heteroscedasticity Test}

Based on the results of the heteroscedasticity test, it can be seen that the significant value of the independent variables is greater than 0.05 so that it can be said that the model is free from heteroscedasticity.

\subsection{Multiple Linear Regression Analysis}

Multiple linear regression is used to determine the effect of capital structure, liquidity and profitability on firm value in the food and beverage sub-sector on the Indonesia Stock Exchange. Based on the calculation results of the IBM SPSS Statistics Version 24 program, the results are as presented in Table 1

Table 1 Multiple Linear Regression

Coefficients $^{\mathrm{a}}$

\begin{tabular}{|c|c|c|c|c|c|c|}
\hline \multirow{2}{*}{\multicolumn{2}{|c|}{ Model }} & \multicolumn{2}{|c|}{$\begin{array}{l}\text { Unstandardized } \\
\text { Coefficients }\end{array}$} & \multirow{2}{*}{$\begin{array}{c}\text { Standardized } \\
\text { Coefficients } \\
\text { Beta } \\
\end{array}$} & \multirow[t]{2}{*}{$\mathrm{t}$} & \multirow[t]{2}{*}{ Sig. } \\
\hline & & B & Std. Error & & & \\
\hline \multirow[t]{4}{*}{1} & (Constant) & 9,366 & 4,114 & & 2,277 & ,028 \\
\hline & $\mathrm{X} 1$ & $-4,890$ & 2,248 &,- 271 & $-2,175$ & , 035 \\
\hline & $\mathrm{X} 2$ &,- 023 & , 011 &,- 239 & $-2,080$ & ,043 \\
\hline & X3 & ,279 & ,031 & ,860 & 8,947 & ,000 \\
\hline
\end{tabular}

a. Dependent Variable: Y

Source: Data processing results, 2021

Based on the values in Table 1, an equation for the multiple linear regression model of the effect of capital structure, liquidity, and profitability on firm value can be made as follows. $\hat{Y}=9,366-4,890 X_{1}-0,023 X_{2}+0,279 X_{3}$

\subsection{Statistical $t$ test (t test)}

According to Ghozali (2016:98) the t statistical test basically shows how far the influence of one independent variable individually (partial) in explaining the variation of the dependent variable.

a. The effect of capital structure (X1) on firm value (Y) in the food and beverage sub-sector on the Indonesia Stock Exchange.

Based on Table 1, the value for the capital structure (X1) is equal to the sig value of $0.035<(0.05)$, because the significance value obtained is 0.035 which is smaller than 0.05 . Then the capital structure (X1) has a significant negative effect on firm value $(\mathrm{Y})$. This means that $\mathrm{H} 1$ is accepted.

b. Effect of liquidity (X2) on firm value (Y) in the food and beverage sub-sector on the Indonesia Stock Exchange Based on Table 1, the value for liquidity (X2) is obtained with a sig value of $0.043<(0.05)$, because the significance value obtained is 0.043 which is smaller than 0.05 . Then liquidity (X2) has a significant negative effect on firm value (Y). This means that $\mathrm{H} 2$ is rejected.

c. The effect of profitability (X3) on firm value $(\mathrm{Y})$ in the food and beverage sub-sector on the Indonesia Stock Exchange.

Based on Table 1, the value for the profitability variable (X3) with a sig value of $0.000<(0.05)$, because the significance value of 0.000 is smaller than 0.05 , profitability has a significant positive effect on firm value.

\section{CONCLUSION}

Based on the results of the discussion in the previous chapters, it can be concluded as follows: (1) Capital structure has a negative effect on firm value in food and beverage sub-sector companies on the Indonesia Stock Exchange; (2) Liquidity has a negative effect on firm value in food and beverage sub-sector companies on the Indonesia Stock Exchange; (3) Profitability has a positive effect on firm value in food and beverage sub-sector companies on the Indonesia Stock Exchange. Based on the conclusions, it can be put forward some suggestions that can be given as consideration in investing in the Indonesia Stock Exchange are as follows: (1) For further researchers are expected to develop this research by including or increasing the number of variables that can affect the value of the company such as company growth, dividend policy and free cash flow; (2) For company management, the results of the study found that profitability is able to increase the value of the company, so it is necessary to maintain return on equity so that profit remains sustainable; (3) For investors, in making investment decisions, investors and potential investors should consider profitability because profitability was found to have a positive effect on firm value. 
International Journal of Social Science (IJSS)

Vol.1 Issue.3 October 2021, pp: 145-150

ISSN: 2798-3463 (Printed) | 2798-4079 (Online)

DOI: $\underline{\text { https://doi.org/10.53625/ijss.v1i3.406 }}$

\section{REFERENCES}

[1] S. Hermuningsih, "Profitability, Growth Opportunity, Capital Structure And The Firm Value," Bulletin of Monetary, Economics and Banking, pp. 115-135, 2013.

[2] A. Sartono, Manajemen Keuangan Teori Dan Aplikasi, Yogyakarta: BPFE, 2014.

[3] Brigham, E.F., dan Houston, J.F. 2010. Dasar-dasar Manajemen Keuangan. Jakarta: Salemba.

[4] Brigham, E.F., dan Houston, J.F. 2013. Dasar-dasar Manajemen Keuangan. Jakarta: Salemba

[5] Yuliana, Akbar. D. A \& Aprillia. R (2013). Pengaruh Struktur Modal Dan Return On Equity (ROE) Terhadap Nilai Perusahaan Pada Perusahaan Sektor Pertanian Di Bursa Efek Indonesia. Eprints.mdp.ac.id/688/1/Jurnal 2009210008 Yuliana.pdf

[6] I. Fahmi, Pengantar Manajemen Keuangan Teori dan Soal Jawab, Bandung: Alfabeta, 2016.

[7] I. Ghozali, Aplikasi Analisis Multivariate dengan Program IBM SPSS 21, Semarang: Badan Penerbit Universitas Diponegoro, 2016.

[8] S. Husnan and E. Pudjiastuti, Dasar- Dasar Manajemen Keuangan, Yogyakarta: YKPN, 2012.

[9] J. Jacob and F. A. Taslim, "The Impacts of The Ratio of Liquidity, Activity And ProfitabilityTowards Company Value With Dividend Policy As Intervening Variables," IOSR Journal of Business and Management (IOSR$J B M)$, vol. 19, no. 10, pp. 01-07, 2017.

[10] N. L. P. Wiagustini, Dasar - Dasar Manajemen Keuangan, Denpasar: Udayana Press, 2014.

[11]E. F. Brigham and J. Houston, Dasar-dasar Manajemen Keuangan, Jakarta: Salemba Empat, 2011.

[12] P. Y. S. Dewi, G. A. Yuniarta and A. W. T. Atmadja, "Pengaruh Struktur Modal, Pertumbuhan Perusahaan dan Profitabilitas Terhadap Nilai Perusahaan pada Perusahaan LQ45 di BEI Periode 2008-2012," e-Juornal S1 Akuntansi Universitas Pendidikan Ganesha, vol. 2, no. 1, 2014.

[13] J. Winarto, "The Determinants of Manufacturer Firm Value in Indonesia Stock Exchange," Int. J. Information, Bus. Manag., vol. 7, no. 4, pp. 323-, 2015, [Online]. Available: http://ijibm.site666.com/IJIBM_Vol7No4_Nov2015.pdf\#page=206.

[14]A. Mandalika, "Pengaruh Struktur Aktiva, Struktur Modal, Dan Pertumbuhan Penjualan Terhadap Nilai Perusahaan Pada Perusahaan Publik Yang Terdaftar Di Bursa Efek Indonesia (Studi Pada Sektor Otomotif)," J. Berk. Ilm. Efisiensi, vol. 16, no. 1, pp. 207-218, 2016, [Online]. Available: https://ejournal.unsrat.ac.id/index.php/jbie/article/download/10629/10218.

[15] W. A. and R. Corry, "Pengaruh Tingkat Likuiditas, Solvabilitas, Aktivitas, Dan Profitabilitas Terhadap Nilai Perusahaan Pada Perusahaan Real Estate Dan Property Di BEI Tahun 2006 - 2008," pp. 67-75, 2008.

[16]C. W. Anzlina and Rustam, "Pengaruh Tingkat Likuiditas, Solvabilitas, Aktivitas, Dan Profitabilitas Terhadap Nilai Perusahaan Pada Perusahaan Real Estate Dan Property Di BEI Tahun 2006 - 2008," Jurnal Ekonom, vol. 16, no. 2, pp. 67-75, 2013.

[17] A. S. M. Dewi and A. Wirajaya, "Pengaruh Struktur Modal, Profitabilitas Dan Ukuran Perusahaan Pada Nilai Perusahaan," E-Jurnal Akuntansi Universitas Udayana, vol. 4, no. 2, pp. 358-372, 2013.

[18] N. K. A. Sudiani and N. P. A. Darmayanti, "Pengaruh Profitabilitas, Likuiditas, Pertumbuhan, Dan Investment Opportunity Set Terhadap Nilai Perusahaan," E-Jurnal Manajemen Unud,, vol. 5, no. 7, pp. 4545-4574, 2016. 
